\title{
The best incubation time for primary productivity of phytoplankton in Laguna Lake, North Maluku, Indonesia
}

\author{
YULIANA ${ }^{\vee}$, MUHAMMAD IRFAN \\ Faculty of Fisheries and Marine Science, Universitas Khairun. Gambesi, Ternate 97719, North Maluku, Indonesia. Tel.: +62-921-3121854, \\ Fax.: +62-921-3110901. ‘email: yulianarecar@gmail.com
}

Manuscript received: 17 February 2018. Revision accepted: 12 May 2018.

\begin{abstract}
Yuliana, Irfan M. 2018. The best incubation time for primary productivity of phytoplankton in Laguna Lake, North Maluku, Indonesia. Biodiversitas 19: 1021-1028. Primary productivity of phytoplankton is a source of energy and organic matter utilized by organisms at higher food chain levels. The measurement of the high rate of primary productivity can be done through the incubation of sample water at a particular time and time depending on sunlight intensity. This study aimed to estimate the best incubation time to achieve the highest primary productivity of phytoplankton in Laguna Lake, Ternate City, North Maluku Province, Indonesia in February 2017. The study was conducted at one location with four different levels of depth of $0,5,10$, and 15 meters, and at three incubation times, i.e., 09:00-13:00, 10:00-14:00, and 11:00-15:00 (Eastern Indonesian Time). The chemical and physical parameters of radiance, temperature, $\mathrm{pH}$, nitrate, and orthophosphate content were measured to estimate water quality of the lake. The results of this study showed that were 10 genera of phytoplankton belonging to Bacillariophyceae (6 genera), Chlorophyceae (4 genera), and Cyanophyceae ( 2 genera). The Laguna Lake has temperature ranged between $29.0-31.1^{\circ} \mathrm{C}$, nitrate content of $0.22-0.58 \mathrm{mg}^{-1}$, orthophosphate content of $0.14-0.27 \mathrm{mg} \mathrm{l}^{-1}$, and $\mathrm{pH}$ 7. The primary productivity value at incubation time 09:00-13:00; 10:00-14:00; and 11:00-15:00 were of 101,851-258,278; 40,59-351,643; and 76,197-305,754 $\mathrm{mgC} \mathrm{m}^{-3}$ hours $^{-1}$, respectively. The best incubation time that provides the highest value in the measurement of primary productivity of phytoplankton at Laguna Lake was at 10:00 am to 14:00 pm.
\end{abstract}

Keywords: Incubation time, Laguna Lake, phytoplankton, primary productivity

\section{INTRODUCTION}

The lake is public waters with open ecosystems formed through either volcanic activity (volcanic lakes) or earthquakes (tectonic lakes). The lakes have a complex ecosystem, including different types of biota associated with them. The biota may undergo population dynamic change depending on the condition of the lake. A poor state of lake ecosystems and its biota can be implied from their physical, chemical, and biological characteristics. Aquatic organisms which lived in the waters can determine the level of primary productivity contained in the waters. Thus such organisms can be one of the indicators of water fertility.

The waters fertility may reflect the existence of primary producers (phytoplankton) of the lakes is very important because they are the major contributor to provide organic material needs by other organisms living within. Primary productivity was the number of organic materials produced by autotrophic organisms. This was primarily done by phytoplankton through the process of photosynthesis (Wetzel 1983; Parsons et al. 1984).

Primary productivity of phytoplankton is one source of energy and organic materials utilized by organisms at the higher food chain level. Several factors that affected the primary productivity included sunlight, nutrients, temperature, and community structure and phytoplankton abundance (Nybakken 1982; Wetzel 1983).

Primary productivity is measured by considering the highest current sunlight through carrying out incubation process to calculate the amount of primary productivity. In the incubation, the determination of incubation time is based on the desire of the researcher so that the result of primary productivity of waters is different between one researcher and the other researchers (Tambaru and Samawi 2008). This is because there is no standard in determining the best time in primary productivity measurement, while it is very important to know in the waters. Therefore, it is expected that this research will get the incubation time gives the highest primary productivity value, so that in primary productivity measurement, we get result which is closer to the value of actual primary productivity content in the waters (Tambaru 2000; Tambaru and Samawi 2008).

Laguna Lake is one of the existing lakes in Ternate Island that has great potential as a source of land fisheries and to serve as a tourist attraction site. Currently, the waters have been utilized by the local community as Keramba Jaring Apung (KJA). Laguna Lake is thought to have high primary productivity due to the high intensity of sunlight that penetrated into the lake. This research was aimed to estimate the best incubation time that provides the highest primary productivity of phytoplankton in Laguna Lake.

\section{MATERIALS AND METHODS}

This study was conducted at Laguna Lake, Ternate City, North Maluku Province, Indonesia (Figure 1), in February 2017. There were four depths used in this study, i.e., $0.5,10$, and 15 meters. The incubation time was 
determined following Tambaru (2000) and Yuliana (2006). They considered that the highest primary productivity obtained at the incubation time of at 10:00 to 14:00. However, the sunlight reached the earth surface was varied by time and location, hence we used three periods of incubation time at 09:00-13:00; 10:00-14:00, and 11:0015:00. ; it was repeated three times based on the day. The primary productivity of phytoplankton was measured by the oxygen content in a light-dark bottle after being incubated for 4 hours. We used a $125 \mathrm{ml}$ oxygen bottle for this experiment. Sixteen bottles were used at each incubation time, so there were 48 bottles in total. For every 16 bottles, we put 4 bottles at each depth. Consequently, there were three variations of every 4 bottles, i.e., 2 bright bottles, 1 dark bottle, and 1 initial bottle. The dark bottle was modified by coating with black plastic.

Water sampling was done at each depth by using a water sampler Kemmerer, then put into experimental bottles. Filling the bottle was need to be done carefully to avoid bubbling. Oxygen measurement was carried out first for the of the initial bottle, followed by the other bottles ( 2 bright bottles and one dark bottle). These bottles were incubated at each incubation time set previously, and at each level of depth.

The calculation of primary productivity conducted according to Umaly and Cuvin (1988) with the following formula:
Gross photosynthesis $\left(\mathrm{mgCm}^{-3} \mathrm{~h}^{-1}\right)=\left(\mathrm{O}_{2} \mathrm{BT}\right)-\left(\mathrm{O}_{2} \mathrm{BG}\right)(1000) \times 0.375$ $(\mathrm{PQ})(\mathrm{t})$

Net Photosynthesis $\left(\mathrm{mgCm}^{-3} \mathrm{~h}^{-1}\right)=\left(\mathrm{O}_{2} \mathrm{BT}\right)-\left(\mathrm{O}_{2} \mathrm{BA}\right)(1000) \times 0.375$ $(\mathrm{PQ})(\mathrm{t})$

Where:

$\mathrm{O}_{2}=$ dissolved oxygen $\left(\mathrm{mg} . \mathrm{L}^{-1}\right) ; \mathrm{BT}=$ bright bottle; $\mathrm{BG}$ $=$ dark bottle; $\mathrm{BA}=$ initial bottle; $\mathrm{PQ}=$ result for photosynthesis $(1,2) ; \mathrm{t}=$ length of incubation (hours)

Water samples for phytoplankton specimens were filtered in a volume of 30 liters by using a $25 \mu \mathrm{m}$ pivot plankton net. The filter was transferred to a $35 \mathrm{ml}$ volume bottle and preserved in 4\% formalin; this was conducted at each incubation time at various depths.

The abundance of phytoplankton was calculated based on equation according to APHA (2005):

$$
\mathrm{N}=\mathrm{Oi} / \mathrm{Op} \times \mathrm{Vr} / \mathrm{Vo} \times 1 / \mathrm{Vs} \times \mathrm{n} / \mathrm{p}
$$

\section{Where:}

$\mathrm{N}=$ A number of individuals per liter; $\mathrm{Oi}=$ the glass area of the preparatory cover $\left(\mathrm{mm}^{2}\right)$; Op $=$ area of one field of view $\left(\mathrm{mm}^{2}\right) ; \mathrm{Vr}=$ filtered water volume $(\mathrm{ml}) ; \mathrm{Vo}=$ observed water volume $(\mathrm{ml}) ; \mathrm{Vs}=$ volume of filtered water (L); $\mathrm{n}=$ the number of planktons on the entire field of view; $p=$ the number of observed field of view

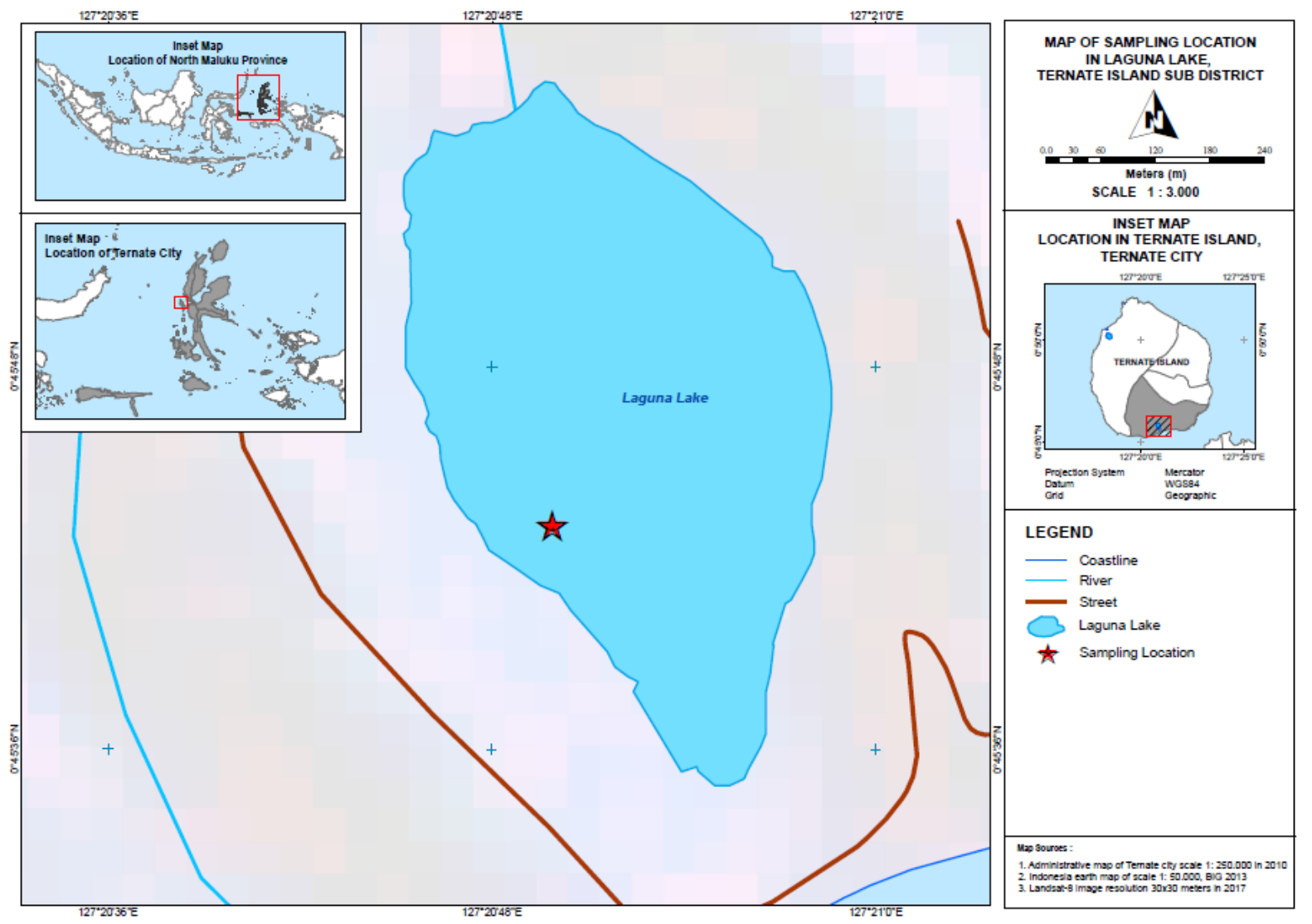

Figure 1. Research location in Laguna Lake, Ternate, North Maluku Province, Indonesia 
Identification of phytoplankton was following Davis (1955), Needham (1962), and Mizuno (1979). Other supporting data were also be recorded on site such as temperature, sunlight, and $\mathrm{pH}$ (as the chemical-physical parameter), while nitrate and orthophosphate were analyzed using spectrophotometer (APHA 2005) in the laboratory of productivity and quality of waters at the Faculty of Marine and Fisheries Sciences Hasanuddin University.

The best incubation time interval in primary productivity was analyzed by using randomized block design (Steel and Torrie 1962), with the following formula:

$$
Y i j=\mu+\sigma i+K j+\varepsilon i j
$$

Where:

Yij = primary productivity; $\mu=$ general middle value; $\sigma \mathrm{i}$ $=\mathrm{i}$-th treatment to-i (incubation time to-i) $\mathrm{Kj}=$ group of $-\mathrm{j}$ (jth depth); $\varepsilon \mathrm{ij}=$ error treatment.

The LSD (least significant difference) test is used to view the highest incubation time interval period.

\section{RESULTS AND DISCUSSION}

\section{The composition of phytoplankton species}

The results of our study found 12 genera of phytoplankton, i.e., Bacillariophyceae (6 genera), Chlorophyceae (4 genera), and Cyanophyceae (2 genera) in Laguna Lake. The number of genera found in Laguna Lake was less than those of Zhao et al. (2016) in Bange Lake who recorded 41 genera, Ganai and Parveen (2014) in Wular Lake who found 64 genera, Rudiyanti et al. (2017) in Jatibarang Reservoir who found 21 genera, and Rahman et al. (2016) in Toba Lake who recorded 35 genera. Among our finding, Bacillariophyceae was the dominant class in all periods of time and depths, followed by Chlorophyceae. This was in accordance with the previous studies (Yuliana and Tamrin 2007; Yuliana 2007; Ikhsan et al. 2015; Ganai and Parveen 2014; Rudiyanti et al. 2017). However, other studies (Umar 2003; El-Karim 2008); Merina et al. 2014) reported that Chlorophyceae was predominant in Juanda Jatiluhur Dam, Lake Manzala, and Maninjau Lake. On the other hand, Cyanophyceae was dominant in Cirata (Baksir 1999), Toba Lake (Rahman et al. 2016), and Lake Kortowskie (Jaworska et al. 2014). Meanwhile, phytoplankton was dominated by nonheterocystous cyanoprokaryotes in Lake Bukoni (Nyakoojo 2010). In freshwater, particularly lakes and reservoirs, phytoplanktons that were dominant, widespread and played an important role in the food chain were Bacillariophyceae, Cyanophyceae, and Chlorophyceae (Ruttner 1973; Boney 1975; Sellers and Markland 1987; Noryadi 1998).

In general, Bacillariophyceae had the highest percentage of abundance $(57 \%)$, and the lowest $(6 \%)$ was Chlorophyceae (Figure 2). These results are different from Liu et al. (2014) in Poyang-Junshan Lake that found the highest grade percentage was Chlorophyta (47.2\%). This figure indicated that Bacillariophyceae have better growth in the Laguna Lake compared to the other phytoplankton.

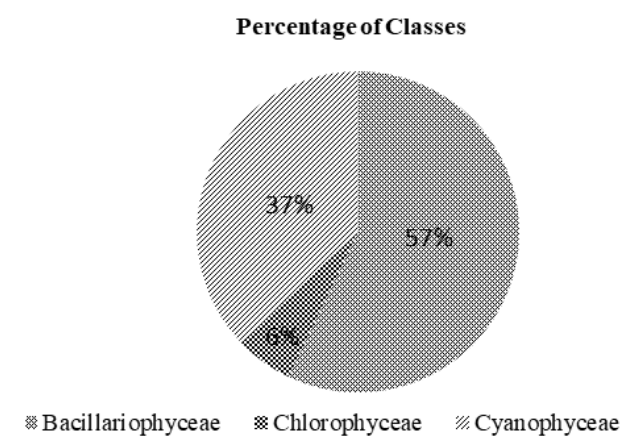

Figure 2. Composition of phytoplankton species at Laguna Lake, Ternate, North Maluku Province, Indonesia

Results from depth analysis (Figure 3) suggested that there was a different dominance of phytoplankton among each depth. At a depth of $0 \mathrm{~m}$, Cyanophyceae was the dominant $(54.1 \%)$, and Chlorophyceae was least dominant (4.1\%). Rahman et al. (2016) also observed that Cyanophyceae was mostly found $(>40 \%)$ in Toba Lake. Meanwhile, Bacillariophyceae was dominant $(56.6 \%)$ in a $5 \mathrm{~m}$ depth, while Chlorophyceae was the least observed $(6.3 \%)$. Bacillariophyceae still dominated $(85.4 \%)$ in the 10 $\mathrm{m}$ depth, while the least dominant was the Cyanophyceae $(1.3 \%)$. Meanwhile, at a depth of $15 \mathrm{~m}$, Cyanophyceae was dominant $(63.2 \%)$, and Chlorophyceae was absent in this depth. The dominance of the Cyanophyceae at a depth of $15 \mathrm{~m}$ was due to the orthophosphate content supporting the growth of phytoplankton. This finding was in agreement to previous studies (Sulastri (2011; Lv et al. (2011; Jiang et al. 2014) who considered that Cyanophyceae was common phytoplankton and very abundant in aquatic conditions with high phosphate concentrations.

Concerning the incubation time (Figure 3), the first incubation time (09:00-13:00) was dominated by Bacillariophyceae $(76.4 \%)$, and Chlorophyceae was least frequently found $(2.4 \%)$. At incubation time II (10:0014:00), Cyanophyceae was mostly observed (51.3\%) while Chlorophyceae was least found $(8.0 \%)$. At incubation time III (11:00-15:00), Bacillariophyceae also dominated $(93.5 \%)$, and the least observed was the Chlorophyceae (1.95\%) (Figure 3).

Our observations on the distribution of phytoplankton Laguna Lake showed that Bacillariophyceae class was found in the highest percentage (the number of genera) at all incubation times and depths, while Chlorophyceae dan Cyanophyceae were found at all incubation times but absent at all depths (Figure 3). Chlorophyceae was not observed at the following condition: at a depth of $0 \mathrm{~m}$ and incubation time I (09:00-13:00), at a depth of $5 \mathrm{~m}$ and incubation time II (10:00-14:00), as well as at a depth of 15 $\mathrm{m}$ at all incubation time. Furthermore, Cyanophyceae class was not recorded at the following condition: at a depth of 0 $\mathrm{m}$ incubation time I and III, at a depth of $5 \mathrm{~m}$ incubation time III, at a depth of $10 \mathrm{~m}$ incubation time I and II, as well as at a depth of $15 \mathrm{~m}$ incubation time II. Nitszchia was a genus of Bacillariophyceae class obtained almost at all incubation times and depths, except for $15 \mathrm{~m}$ incubation time II and III, while Spirogyra (Chlorophyceae class) was only found at incubation time II (10:00-14:00). 
The highest number of genera was found at a depth of 5 $\mathrm{m}$ that was 10 genera, and the lowest number of genera was found at a depth of $0 \mathrm{~m}$. The presence of phytoplankton is influenced by several factors, including nutrients, light conditions, temperature, $\mathrm{pH}$, and predation by zooplankton and planktivorous fish (Lau and Lane 2002; Yu 2010; Jiang et al. 2014). The high number of genera found at a depth of $5 \mathrm{~m}$. The intensity of light at this depth was in the optimum condition so that phytoplankton can perform photosynthesis at their best (Tambaru 2000). Meanwhile, the lowest number of genera was found at a depth of $0 \mathrm{~m}$. The light entering into the column of this waters at this depth was in a much higher intensity exceeding the optimum requirement for the growth of phytoplankton so that it inhibited photosynthesis activity.

The number of genera observed in each incubation time was not too different, are as follows: incubation time I (09:00-13:00): 9 genera, incubation time II (10:00-14:00): 12 genera, and incubation time III (11:00-15:00): 10 genera. This suggests that all genera were found at incubation time II, but not at incubation times I and III.

\section{Abundance of phytoplankton}

The abundance of each (genera) of phytoplankton observed in Laguna Lake was varied, with a range of 412.91 to 71433.93 ind. $^{-1}$. The most abundant phytoplankton was Microcytic (Cyanophyceae class). The presence of Microcytic indicated that Laguna Lake was eutrophic waters. Abrantes et al. (2006), Elliott and May (2007), Groga et al. (2014), and Jiang et al. (2014) reported that some common types of phytoplankton that were very abundant in eutrophic waters were Anabaena, Microcytic, Chroococcus, and filamentous species such Aphanizomenon. Furthermore, Carmichael (2001) and Chen et al. (2008) explained that Anabaena and Microcystis are the toxic phytoplankton types and causes problems associated with hypoxia as well as changes in the structure of biological communities.
Other genera of phytoplankton that were also abundance in Laguna Lake were Nitzschia and Diatoma (Bacillariophyceae), while Anabaena (Cyanophyceae) was dominant in Toba Lake (Rahman et al. 2016) and Cylindrospermopsis raciborskii was dominant in Lagoa Santa (Figueredo and Giani 2009). The different nature of dominance between those lakes may occur due to the differences in water quality, especially the concentration of nutrients contents.

There was a general pattern observed in the abundance of phytoplankton during all incubation times and various depth selected in this study. The highest abundance (120778 ind. $\left.\mathrm{L}^{-1}\right)$ of phytoplankton was at incubation time II (10:00-14:00), and the lowest abundance (20027 ind.L-1) was at incubation time III (11:00-15:00) (Table 1). These values were relatively high compared to those at Laguna Lake (Yuliana 2007), Poyang-Junshan Lake (Liu et al. 2014), and Maltański Reservoir (Kozak et al. 2015).

Table 1. The abundance of phytoplankton in each incubation time at varying depths level in Laguna Lake, Ternate, North Maluku Province, Indonesia

\begin{tabular}{lcc}
\hline Incubation time & Depth $(\mathbf{m})$ & Abundance (ind. $\mathbf{L}^{\mathbf{- 1}}$ ) \\
\hline 09:00-13:00 & 0 & 3716 \\
& 5 & 8258 \\
& 10 & 17755 \\
Total & 15 & 13213 \\
10:00-14:00 & & 42942 \\
& 0 & 40053 \\
& 5 & 75976 \\
Total & 10 & 4336 \\
11:00-15:00 & 15 & 413 \\
& & 120778 \\
& 0 & 1239 \\
& 5 & 5781 \\
Total & 10 & 10942 \\
& 15 & 2065 \\
\hline
\end{tabular}

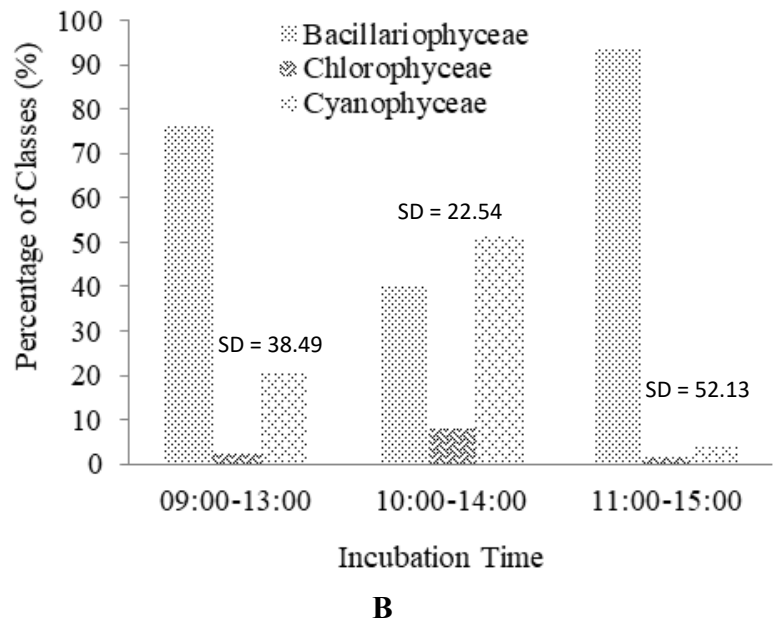

Figure 3. Composition of phytoplankton species based on depth (A) and incubation time (B) in Laguna Lake, Ternate, North Maluku Province, Indonesia 
The highest abundance obtained at a depth of $10 \mathrm{~m} \mathrm{had}$ already been expected. Before the first incubation time was carried out, phytoplankton was still concentrated nearby the bottom of the waters due to the absence of light (Tambaru 2000). Therefore, at the first incubation time, the highest abundance was found in the water column nearby the bottom of the water (10 $\mathrm{m}$ depth).

For the incubation time II (10:00-14:00), the abundance of phytoplankton ranged from 413 to 75976 ind. $\mathrm{L}^{-1}$ (Table 1). The most abundance of phytoplankton was observed at a depth of $5 \mathrm{~m}$ (75976 ind. $\left.\mathrm{L}^{-1}\right)$, and the lowest was at $15 \mathrm{~m}$ (413 ind. $\mathrm{L}^{-1}$ ). The highest abundance found at a depth of 5 $\mathrm{m}$ was due to the intensity of light that was getting stronger and suitable for the development of phytoplankton. During the incubation time II, the light intensity was at its best, so that phytoplankton tended to be more active to breed and grew well in this depth. There was a possibility of an increase of abundance of phytoplankton at a depth of 0 and $5 \mathrm{~m}$ (surface), but at a depth of $15 \mathrm{~m}$ (at the bottom of the waters) phytoplankton abundance decreased. At incubation time III (11:00-15:00), the most abundance was at-10 m depth, and the lowest was at $0 \mathrm{~m}$ depth (Table 1). At this incubation time, the light intensity was still powerful so that phytoplankton could not grow well at depths of 0 and 5 $m$. At incubation time III (11:00-13:00) the intensity of sunlight was still an inhibiting factor for phytoplankton at that depth.

\section{Water quality parameters}

Measurements of several water quality parameters influencing the growth and development of phytoplankton at Laguna Lake were presented in Table 2. The nitrate concentrations measured during the study had a range between 0.22 and $0.58 \mathrm{mg} . \mathrm{L}^{-1}$ (Table 2). Based on the content of nitrate obtained, Laguna Lake was included in the category of eutrophic waters as was explained by Goldman and Horne (1983) that waters with the concentration of nitrate $>0.2$ mg. $\mathrm{L}^{-1}$ were at eutrophic level. Nitrate was the major form of nitrogen in the water characterized by its stability and very soluble in water. Nitrate was easily found in waters contaminated by organic waste. However, the Laguna Lake had not been categorized as contaminated waters because it had a nitrate content of fewer than $1 \mathrm{mg} .1^{-1}$ (Table 2). Weiner (2008) stated that a nitrate concentration between 1 and $2 \mathrm{mg} . \mathrm{L}^{-1}$ could indicate contamination of fertilizer from the activity of farming, and disposal domestic and industrial waste (Alvarez-Vazquez et al. 2014). Mackentum (1969) further reported that phytoplankton requires nitrate content in the range of 0.9 $3.5 \mathrm{mg} . \mathrm{L}^{-1}$ for their optimal growth.

The concentration of orthophosphate obtained during the research had a range between 0.14 and $0.27 \mathrm{mg} . \mathrm{L}^{-1}$ (Table 2). Wu and Wang (2012) explain that the total of orthophosphate concentration $>0.20 \mathrm{mg} . \mathrm{L}^{-1}$ showed a high or eutrophic fertility level. Mackentum (1969) also considered that to the optimal growth of phytoplankton requires orthophosphate concentration in the range of 0.09 $1.80 \mathrm{mg} . \mathrm{L}^{-1}$. Thus the Laguna Lake was considered to having a moderate to high fertility level. However, Bruno et al. (1979 in Sumardianto 1995) stated that the optimal concentration of orthophosphate for the growth of phytoplankton was $0.27-5.51 \mathrm{mg} . \mathrm{L}^{-1}$, if the content were less than $0.02 \mathrm{mg} . \mathrm{L}^{-1}$, it would be an inhibiting factor for phytoplankton growth. Kepmen LH (2004) determined the phosphate threshold value to be $0.015 \mathrm{mg} . \mathrm{L}^{-1}$ or 0.465 $\mu \mathrm{gA} . \mathrm{l}^{-1}$. Following the criteria proposed by Bruno et al. (1979 in Sumardianto 1995) and Kepmen LH (2004), the orthophosphate concentration obtained in Laguna Lake had not been a limiting factor and even a factor supporting the growth and development of phytoplankton.

The temperature measured during the study at Laguna Lake ranged between 29.0 and $31.1^{\circ} \mathrm{C}$ (Table 2). Effendi (2004) stated that the optimum temperature ranges for the growth of phytoplankton in the waters were between 20 $30^{\circ} \mathrm{C}$. The temperature of the Laguna lake was a little higher than suggested by Effendi (2004), but this was still suitable for the growth of phytoplankton.

The $\mathrm{pH}$ value obtained at all depths and incubation times was 7 (Table 2) and was suitable for the optimal growth and development of phytoplankton. Pescod (1973) stated that the ideal $\mathrm{pH}$ for phytoplankton life ranged from 6.5 to 8.0. Effendi (2004) explained that $\mathrm{pH}$ values between 4.5-6.5 could lead to a decrease of diversity and the composition of the plankton.

\section{Primary productivity}

The primary productivity obtained during the study at Laguna Lake had value ranged between 76.197 and $351.643 \mathrm{mgCm}^{-3}$ hour $^{-1}$ (Table 3 ). This value was higher than the results of Feresin et al. (2010) who reported that in a tropical Brazilian shallow lake the primary productivity value ranged between 10.3 to $34.6 \mathrm{mgCm}^{-3} \mathrm{~h}^{-1}$, and Tadonleke et al. (2009) found that the primary productivity in Lake Geneva was $767.5 \mathrm{mgCm}^{-2}$ days $^{-1}$. The primary productivity obtained in this study was varied for each incubation time (Table 3 ). The highest primary productivity was observed at incubation time II, followed by incubation time III, and incubation time I (Figure. 3). As a composite, the highest primary productivity was obtained at incubation time II (1099.871 $\mathrm{mgCm}^{-3}$ hour $\left.^{-1}\right)$, and the lowest was at incubation time I (684.643 $\mathrm{mgCm}^{-3}$ hour $\left.^{-1}\right)$.

Table 2. The water quality parameters measured in Laguna Lake, Ternate, North Maluku Province, Indonesia

\begin{tabular}{|c|c|c|c|c|c|}
\hline \multirow[b]{2}{*}{$\begin{array}{l}\text { Incubation } \\
\text { time }\end{array}$} & \multirow[b]{2}{*}{$\begin{array}{c}\text { Depth } \\
\text { (m) }\end{array}$} & \multicolumn{4}{|c|}{ Parameters } \\
\hline & & $\begin{array}{c}\text { Temp. } \\
\left({ }^{\circ} \mathrm{C}\right)\end{array}$ & pH & $\begin{array}{l}\text { Nitrate } \\
\left(\mathrm{mg} \cdot \mathrm{L}^{-1}\right)\end{array}$ & $\begin{array}{c}\text { Ortho- } \\
\text { phosphate } \\
\left.\text { (mg.L } \mathrm{L}^{-1}\right)\end{array}$ \\
\hline \multirow[t]{4}{*}{ 09:00-13:00 } & 0 & 29.0 & 7 & 0.28 & 0.15 \\
\hline & 5 & 29.0 & 7 & 0.35 & 0.20 \\
\hline & 10 & 29.2 & 7 & 0.24 & 0.22 \\
\hline & 15 & 29.2 & 7 & 0.57 & 0.25 \\
\hline \multirow{5}{*}{ 10:00-14:00 } & 0 & 30.6 & 7 & 0.26 & 0.14 \\
\hline & 5 & 30.2 & 7 & 0.30 & 0.21 \\
\hline & 10 & 30.4 & 7 & 0.22 & 0.21 \\
\hline & 15 & 30.0 & 7 & 0.58 & 0.27 \\
\hline & 0 & 31.1 & 7 & 0.25 & 0.17 \\
\hline \multirow[t]{3}{*}{$11: 00-15: 00$} & 5 & 30.8 & 7 & 0.32 & 0.19 \\
\hline & 10 & 30.1 & 7 & 0.23 & 0.23 \\
\hline & 15 & 30.3 & 7 & 0.53 & 0.24 \\
\hline
\end{tabular}


The high primary productivity observed at incubation time II was caused by the best utilization of light by phytoplankton during which period light came on a broader angle and reached the peak of irradiation with the maximum arrival angle between 12:00-13:00 (Tambaru 2000). The light intensity reaching the surface of the waters penetrates strongly into the water column in greater arrival angle, causing the higher intensity of sunlight to penetrate into the waters and vice versa (Parsons et al. 1984). This high intensity of light affected the utilization of more light by phytoplankton for the process of photosynthesis. Similarly, regarding light adjustment by phytoplankton in performing its activity, it was presumed to have been achieved in period II. This was due to the adjustment that had taken place at the sunrise time since at 06:00 am, so the overall light intensity was utilized by phytoplankton for photosynthesis.

The incubation time I gave the lowest productivity among the three incubation times. The new phytoplankton performed the level of adjustment with the conditions of light intensity that just entered the waters in the morning. The phytoplankton at that time has just adjusted to the water layer where the light intensity was following their needs and developments. Jeffries and Mills (1996 in Effendi 2004) reported that the great light intensity affected the behavior of aquatic organisms. Planktonic algae showed a response to the presence of light intensity by making a vertical movement to the water column. This period of adjustment caused by phytoplankton did not perform photosynthesis optimally. These phenomena caused the primary productivity level in this period were lower than incubation time II and III.

Primary productivity obtained at Laguna Lake was varied at each level of depth (Table 3 ). The highest value was found at a depth of $5 \mathrm{~m}$, and the lowest was at a depth of $15 \mathrm{~m}$. The highest primary productivity content found at a depth of $5 \mathrm{~m}$ was caused mainly by light and nutrients. At this depth, the intensity of sunlight entering to the water column at all incubation times was at optimum conditions for phytoplankton. Similarly, the nutrient content (nitrates and orthophosphates) at this depth had nitrate content of 0.30 to $0.35 \mathrm{mg} . \mathrm{L}^{-1}$ and orthophosphate content of 0.19 $0.21 \mathrm{mg} . \mathrm{L}^{-1}$.

The concentrations of nitrates and orthophosphates were at a suitable level for phytoplankton to grow and develop. The light conditions and nutrient content that was suitable for phytoplankton caused these organisms to be able to perform optimum photosynthesis. The lowest primary productivity content at a depth of $15 \mathrm{~m}$, this mainly due to the intensity of sunlight resulted in low the nutrient content (nitrates and orthophosphates) compared to those at a depth of $5 \mathrm{~m}$. The concentrations of each nutrient at a depth of $15 \mathrm{~m}$ were nitrate: $0.53-0.57 \mathrm{mg} . \mathrm{L}^{-1}$ and orthophosphate: $0.24-0.27 \quad \mathrm{mg} . \mathrm{L}^{-1}$. The primary productivity of phytoplankton at this depth was found to be lower compared to other depths (depths of 0,5 , and $10 \mathrm{~m}$ ).
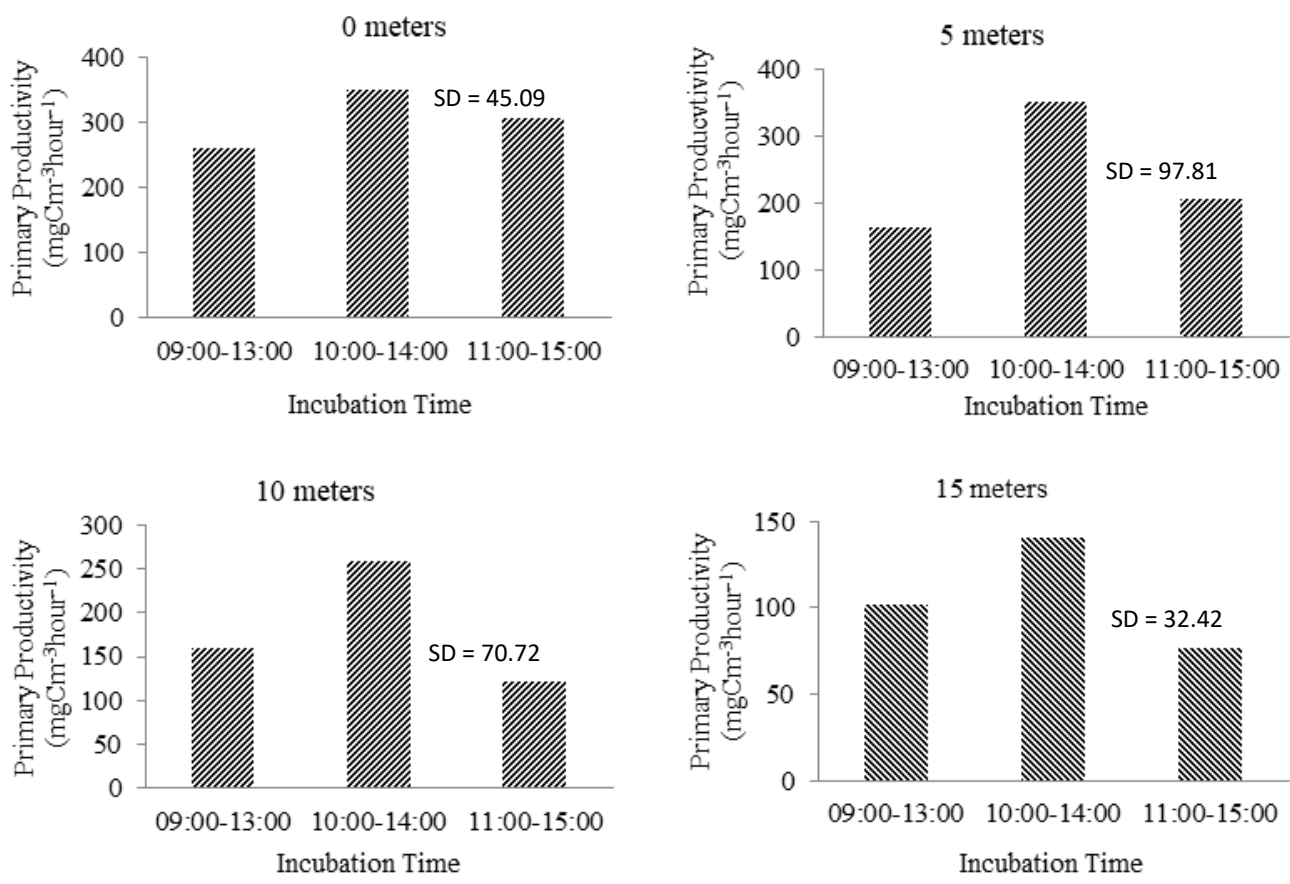

Figure 3. The primary productivity value of phytoplankton at each incubation time and several levels of depths at in Laguna Lake, Ternate, North Maluku Province, Indonesia 
Table 3. The Primary Productivity Value at each incubation time and various depth in Laguna Lake, Ternate, North Maluku Province, Indonesia

\begin{tabular}{lcc}
\hline Incubation time & Depth $(\mathbf{m})$ & $\mathbf{P P}\left(\mathbf{m g C m}^{-\mathbf{3}} \mathbf{h o u r}^{-\mathbf{1}}\right.$ \\
\hline 09:00-13:00 & 0 & 258.278 \\
& 5 & 164.790 \\
& 10 & 159.724 \\
& 15 & 101.851 \\
& & \\
10:00-14:00 & 0 & 348.408 \\
& 5 & 351.643 \\
& 10 & 259.230 \\
& 15 & 140.590 \\
11:00-15:00 & 0 & 305.754 \\
& 0 & 208.065 \\
& 5 & 122.430 \\
& 10 & 76.197 \\
\hline
\end{tabular}

When the content of primary productivity of phytoplankton at Laguna Lake was examined at each depth, the highest primary productivity level was observed at incubation time II (348.408 $\mathrm{mgCm}^{-3}$ hour $\left.^{-1}\right)$, and the lowest was at incubation time I $\left(258.278 \mathrm{mgCm}^{-3}\right.$ hour $\left.^{-1}\right)$. At a depth of $5 \mathrm{~m}$, the highest productivity was at incubation time II (351.643 $\mathrm{mgCm}^{-3}$ hour $\left.^{-1}\right)$, and the lowest was at incubation time II (164.79 $\mathrm{mgCm}^{-3}$ hour $\left.^{-1}\right)$. At a depth of $10 \mathrm{~m}$, the highest value was at incubation time II (259.23 $\mathrm{mgCm}^{-3}$ hour $\left.^{-1}\right)$, and the lowest was at incubation time III $\left(122.43 \mathrm{mgCm}^{-3}\right.$ hour $\left.^{-1}\right)$. At a depth of $15 \mathrm{~m}$, the highest value was at incubation time II $\left(140.59 \mathrm{mgCm}^{-}\right.$ ${ }^{3}$ hour $\left.^{-1}\right)$, and the lowest was at incubation time III (76.197 $\mathrm{mgCm}^{-3}$ hour $^{-1}$ ).

Observation on incubation times used in this study showed that the difference of light period affected the primary productivity of phytoplankton in the Laguna Lake. The results of LSD test showed the highest incubation time was obtained at incubation time II (10:00-14:00). During this incubation time, the intensity of sunlight was at the optimal condition for the growth of phytoplankton to produce the highest level of primary productivity.

It can be concluded that the primary productivity observed during the study ranged from 76.197-351.643 $\mathrm{mgC} \mathrm{m}^{-3}$ hours $^{-1}$. The differences of light period (time interval) affected the primary productivity of phytoplankton in Laguna Lake, with the highest primary productivity value obtained at incubation II (10:00-14:00), followed by incubation time III (11:00-15:00), and I (09:00-13:00).

\section{REFERENCES}

Abrantes N, Antunes SC, Pereira MJ, Goncalves F. 2006. Seasonal succession of cladocerans and phytoplankton and their interactions in a shallow eutrophic lake (Lake Vela, Portugal). Acta Oecologica 29 (1): 54-64.

Alvarez-Vazquez LJ, Fernandez FJ, Martinez A. 2014. Optimal control of eutrophication processes in a moving domain. J Franklin Inst 351 (8): $4142-4182$.
APHA [American Public Health Association]. 2005. Standard methods for the examination of water and wastewater including bottom sediment and sludges. 17th ed. Amerika Publication Health Association Inc., New York.

Baksir, A. 1999. Hubungan antara Produktivitas Primer Fitoplankton dan Intensitas Cahaya di Waduk Cirata, Kabupaten Cianjur Jawa Barat. [Thesis]. Program Pascasarjana Institut Pertanian Bogor, Bogor. [Indonesian]

Boney CAD. 1975. Phytoplankton, $1^{\text {st }}$ ed. The Camelot Press Ltd., Southampton, UK.

Carmichael WW. 2001. Health effects of toxin-producing cyanobacteria: "the CyanoHA s". Human Ecol Risk Assess 7 (5): 1393-1407.

Chen W, Song LR, Peng L, Wan N, Zhang XM, Gan NQ. 2008. Reduction in microcystin concentrations in large and shallow lakes: water and sediment interface contributions. Water Res 42 (3): 763 773.

Davis GC. 1955. The marine and freshwater plankton. Michigan State University Press, USA.

Effendi H. 2004. Telaah kualitas air bagi pengelolaan sumberdaya dan lingkungan perairan. Kanisius, Yogyakarta. [Indonesian]

Elliott JA, May L. 2007. The sensitivity of phytoplankton in Loch Leven (U.K.) to changes in nutrient load and water temperature. Freshw Biol 53 (1): 32-41.

El-Karim MSA. 2008. Monthly variations of phytoplankton communities in Lake Manzala. Global Veterinaria 2 (6): 343-350.

Feresin EG, Arcifa MS, Silva LHS, Esguícero ALH. 2010. Primary productivity of the phytoplankton in a tropical Brazilian shallow lake: experiments in the lake and in mesocosms. Acta Limnologica Brasiliensia 22 (4): 384-396.

Figueredo CC, Giani A. 2009. Phytoplankton community in the tropical lake of Lagoa Santa (Brazil): Conditions favoring a persistent bloom of Cylindrospermopsis raciborskii. Limnologica 39: 264-272.

Ganai AH, Parveen S. 2014. Effect of physicochemical conditions on the structure and composition of the phytoplankton community in Wular Lake at Lankrishipora, Kashmir. Intl J Biodiv Conserv 6 (1): 71-84.

Goldman CR, Horne AJ. 1983. Limnology. McGraw-Hill Book Company, New York.

Groga N, Ouattara A, Koulibaly A, Dauta A, Amblard C, Laffaile P, and Gourene G. 2014. Dynamic and Structure of Phytoplankton Community and Environment in the Lake Taabo (Côte d'Ivoire). J Publ Environ Health 1 (3): 70-86.

Ikhsan M, Izmiarti, Zakaria IJ. 2015. Composition and Community Structure of Phytoplankton in Diatas Lake Solok, West Sumatera. Jurnal Biologi Universitas Andalas (J Biol UA) 4: 145-152.

Jaworska B, Dunalska J, Górniak D, Bowszys M. 2014. Phytoplankton dominance structure and abundance as indicators of the trophic state and ecological status of Lake Kortowskie (northeast Poland) restored with selective hypolimnetic. Arch Pol Fish 22: 7-15.

Jiang YJ, He W, Liu WX, Qin N, Ouyang HL, Wang QM, Kong XZ, He QS, Yang C, Yang B, Xu FL. 2014. The seasonal and spatial variations of phytoplankton community and their correlation with environmental factors in a large eutrophic Chinese lake (Lake Chaohu). Ecol Indicat 40: 58-67.

Keputusan Kantor Menteri Negara Kependudukan dan Lingkungan Hidup No. 51 tahun 2004. Tentang Baku Mutu Air Laut. Kantor Menteri Negara Lingkungan Hidup, Jakarta. [Indonesian]

Kozak A, Goldyn R, Dondajewska. 2015. Phytoplankton composition and abundance in restored maltański reservoir under the influence of physicochemical variables and zooplankton grazing pressure. PLoS ONE 10 (4): e0124738. DOI: 10.1371/journal.pone.0124738

Lau SSS, Lane SN. 2002. Biological and chemical factors influencing shallow lake eutrophication: a long-term study. Sci Total Environ 288 (3): 167-181.

Liu X, Qian KM, Tan GL, Xing JS, Li M, Chen YW. 2014. Phytoplankton community structure and its succession in isolated lakes of PoyangJunshan Lake. Huan Jing Ke Xue 35 (7): 2557-2564.

Lv J, Wu H, Chen M. 2011. Effects of nitrogen and phosphorus on phytoplankton composition and biomass in 15 subtropical, urban shallow lakes in Wuhan, China. Limnologica 41 (1): 48-56.

Mackentum KM. 1969. The Practice of Water Pollution Biology. United States Departement of Interior, Federal Water Pollution Control Administration, Division of Technical Support, Washington DC.

Merina G, Afrizal S, Izmiarti. 2014. Composition and Structure of Phytoplankton Community at Maninjau Lake West Sumatera. Jurnal Biologi Universitas Andalas (J Biol UA) 3: 267-274. 
Mizuno T. 1979. Illustrations of the Freshwater Plankton of Japan. Hoikusha Publishing Co Ltd. Osaka.

Needham, P. 1962. A Guide to The Study of Fresh Water Biology. Holden-Day, Inc., San Francisco.

Noryadi. 1998. Struktur komunitas dan biomassa fitoplankton dan kaitannya dengan nitrogen-fosfor pada lapisan fotik di gradien longitudinal Waduk Juanda. [Thesis]. Program Pascasarjana Institut Pertanian Bogor, Bogor. [Indonesian]

Nyakoojo C. 2010. The composition and abundance of phytoplankton in Lake Bukoni, western Uganda. African J Ecol 48 (4): 1039-1044.

Nybakken JW. 1982. Marine Biology: An Ecological Approach. Harper \& Row, New York.

Parsons TR, Takashi M, Hargrave B. 1984. Biological Oceanographic Processes. 3rd ed. Pergamon Press, Oxford.

Pescod MB. 1973. Investigation of Rational Effluent and Stream Standard for Tropical Countries. AIT, Bangkok.

Rahman A, Pratiwi NTM, Hariyadi S. 2016. The Structure of phytoplankton communities in Lake Toba, North Sumatera. Jurnal Ilmu Pertanian Indonesia 21: 120-127. [Indonesian]

Rudiyanti S, Anggoro S, Rahman A. 2017. Mapping of trophic states based on nutrients concentration and phytoplankton abundance in Jatibarang Reservoir. 3rd International Conference on Tropical and Coastal Region Eco Development 2017. IOP Publishing. IOP Conf. Series: Earth and Environmental Science 116 (2018): 012048. DOI:10.1088/1755-1315/116/1/012048

Ruttner F. 1973. Fundamental of Limnology. 3rd ed. University of Toronto Press, Toronto.

Seller BH, Markland HR. 1987. Decaying Lakes; The Origins And Control Of Culture Eutrophication. John Willey \& Sons Inc, New York.

Steel RGD, Torrie JH. 1962. Principles and Procedures of Statistics. (With special Reference to the Biological Sciences.) McGraw-Hill Book Company, New York.

Sulastri. 2011. Perubahan temporal komposisi dan kelimpahan fitoplankton di Situ Lembang, Jawa Barat. Limnotek 18 (1): 1-14. [Indonesian]

Sumardianto. 1995. Struktur komunitas fitoplankton di perairan Teluk Pelabuhan Ratu, Jawa Barat. [Hon. Thesis]. Program Studi Manajemen Sumber daya Perairan Fakultas Perikanan Institut Pertanian Bogor, Bogor. [Indonesian]
Tadonleke RD, Lazzarotto J, Anneville O, Druart JC. 2009. Phytoplankton productivity increased in Lake Geneva despite phosphorus loading reduction. J Plankton Res 31 (10): 1179-1194.

Tambaru R. 2000. Pengaruh Waktu Inkubasi terhadap Produktivitas Primer di Perairan Teluk Hurun. [Thesis]. Program Pascasarjana, Institut Pertanian Bogor, Bogor. [Indonesian]

Tambaru R, Samawi MF. 2008. Penentuan standar pengukuran produktivitas primer fitoplankton di Perairan Spermonde. Torani 3: 23-28. [Indonesian]

Umaly RC, Cuvin LA. 1988. Limnology: laboratory and field guide physicochemical factors, biology factors. National Book Store Publ., Manila.

Umar, C. 2003. Struktur Komunitas dan Kelimpahan Fitoplankton dalam Kaitannya dengan Kandungan Unsur Hara (Nitrogen dan Fosfor) dari Budidaya Ikan dalam Keramba Jaring Apung di Waduk Ir. H. Juanda Jatiluhur Jawa Barat. [Thesis]. Program Pascasarjana Institut Pertanian Bogor, Bogor. [Indonesian]

Weiner ER. 2008. Applications of Environmental Aquatic Chemistry. CRC Press, New York.

Wetzel RG. 1983. Limnology. W.B. Sounders Company, Philadelphia. $\square$

Wu FF, Wang X. 2012. Eutrophication evaluation based on set pair analysis of Baiyangdian Lake, North China. Procedia Environ Sci 13: 1030-1036.

Yu T. 2010. Phytoplankton Community Structure in Chaohu Lake. [Thesis]. Anhui University, Hefei, CN:.

Yuliana, Tamrin. 2007. Fluctuation and abundance of phytoplankton at Laguna Lake Ternate, North Moluccas. J Fish Sci 9: 288-296.

Yuliana.2006. Phytoplankton primary productivity in many light periodicities at Kao Bay, North Halmahera District. J Fish Sci 8 (2): 215-222.

Yuliana. 2007. The community structure and abundance of phytoplankton in relation to the physics-chemical parameters of the waters at Lake Laguna Ternate, North Maluku. Jurnal Ilmiah Ilmu Peternakan dan Perikanan Protein 14: 85-92.

Zhao W, Zhao Y, Wang Q, Zheng M, Wei J, Wang S. 2016. The community structure and seasonal dynamics of plankton in Bange Lake, northern Tibet, China. Chinese J Oceanol Limnol. 34 (6): 11431157 